REPORTS OF MORPHOLOGY
$\begin{gathered}\text { Official Journal of the Scientific Society of Anatomists, } \\ \text { Histologists, Embryologists and Topographic Anatomists } \\ \text { of Ukraine } \\ \text { journal homepage: https://morphology-journal.com }\end{gathered}$

\title{
The role of steroid receptors in the pathogenesis of adenomyosis in the presence of concomitant endometrial pathology in postmenopause
}

\section{Honcharenko G.Yu.}

Odessa National Medical University, Odessa, Ukraine

\section{ARTICLE INFO}

Received: 21 November, 2018

Accepted: 11 January, 2019

UDC: $618.145-007.415-06-092:$

577.175.62]-053.87

\section{CORRESPONDING AUTHOR}

e-mail: 270916gr@gmail.com Honcharenko G.Y.

\begin{abstract}
Determining the pathogenesis of adenomyosis in postmenopausal women is promising, as it will allow a more thorough study of the mechanisms of hormonal changes and resolve issues related to adenomyosis in women of reproductive age. The purpose of the study is to establish the role of steroid receptors in the pathogenesis of adenomyosis in the presence of concomitant endometrial pathology in postmenopausal women. Study material is removed uteri with parovaria from 117 patients of 49-76 years old. The cases were divided into 4 groups depending on the presence of adenomyosis (AM) and background pathology (endometrioid carcinoma of the endometrium (ECE) and endometrial hyperplasia (EHP)): 1) 27 women with adenomyosis and EHP; 2) 30 women with adenomyosis and ECE; 3) 30 women with adenomyosis and age-related changes in the endometrium; 4) 30 women with age-related changes without AM (comparison group). The immunohistochemical reaction was carried out using primary antibodies to estrogen (ER), progesterone (PR) and androgen (AR) receptors. Statistical processing was carried out using parametric methods of variation statistics (calculated the arithmetic mean, standard deviation, confidence interval, Student criterion). The predominance of the ER expression in the glandular and stromal components of the eutopic endometrium in the presence of $A M$ and hyperplastic processes was compared with the comparison group $(p<0.01)$. A high level of ER expression is characteristic of the epithelium of the endometrium with EHP (7.333 \pm 0.314$)$ and $E C E(6.200 \pm 0.712)$ rather than for the endometrium with atrophic changes in the presence of $A M$ (4.433 \pm 0.773$)$. In the stroma, a high ER activity was detected with EHP $(7.148 \pm 0.276)$ rather than with atrophic changes $(4.567 \pm 0.738)$ and ECE (4.167 \pm 0.602$)$. It was established that in the epithelium of adenomyosis foci, ER expression indices were

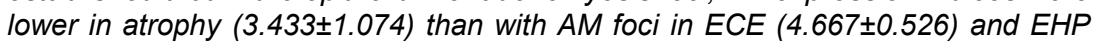
(5.148 \pm 0.745$)$. In the stroma of adenomyosis foci, ER expression is higher in EHP than in ECE and atrophy. The activity of PR in the eutopic endometrium decreases from simple non-typical to complex atypical EHP and in patients with adenomyosis and ECE, as the degree of differentiation of cells of ECA decreases (from G1 to G3 ECE). A minimal expression of $P R$ was found in the comparison group. In the cells of internal endometriosis there were positive indices of immunohistochemical reaction with $P R$. There were obtained minimum scores for receptor expression of $A R$ in eu- and ectopic endometria. Conclusion: adenomyosis foci have a regulatory effect on the uterine endometrium, stimulating the expression of $E R$ and, to a lesser extent, $P R$, and do not affect the level of AR in the eutopic endometrium.
\end{abstract}

Keywords: adenomyosis, postmenopause, estrogen receptors, progesterone receptors, androgen receptors.

\section{Introduction}

To date, the problem of adenomyosis is urgent and raises many questions from representatives of different medical specialties regarding the methods of diagnosis, the effectiveness of the therapy applied, the prevention of the disease [14, 15, 17, 25, 27].

To address these or other issues related to the specified 
pathology, it is necessary to study the features of the pathogenesis of the disease as a key point in the formation of any pathological process. Undoubtedly, hormonal and immunological disorders play a leading role in the development of adenomyosis [8, 9, 23, 24]. In the presence of endometriosis of any localization crucial among all modern methods of examination belongs to morphological research $[3,25]$. Determination of immunohistochemical indicators of the expression of eutopic and ectopic endometrial receptors provides an opportunity to understand the mechanisms of emergence and progression of endometrioid disease. There is no single view of the manifestation of the activity of the receptor apparatus of ectopic foci, but the views of all authors agree on one thing: the stromal and epithelial components of the eutopic endometrium in the presence of internal endometriosis differ from that of healthy women in structure, level of activity of processes of proliferation, proliferation, proliferation, proliferation the functioning of the proteolytic system [6, 28]. All known works to study this pathology are aimed at determining the level of expression of receptors of foci of adenomyosis in women of reproductive and premenopausal age [8, 10, 27, 29]. Given the increase in life expectancy, postmenopausal women are more than a third of their lives in this phase [2]. However, the receptor apparatus of the foci of adenomyosis in postmenopausal women and the correlation between eu- and ectopic endometrias remain poorly understood. The study of the problem of adenomyosis in postmenopausal women will allow to study more carefully the complex mechanisms of hormonal changes and their role in the pathogenesis of internal endometriosis, and the greater availability of pathohistological preparations of the removed uterus of this age group allows to study in detail the receptor apparatus and local transformations in the uterus. In addition, in this category of women the range of concomitant pathology of the reproductive system is wider, which certainly influences the development of the disease and may indicate the comorbidity of such diseases [13, 16, 26]. The establishment of separate links in the pathogenesis of adenomyosis, both isolated and in the presence of concomitant endometrial pathology, in post-menopausal women will help address adenomyosis-related issues in women of reproductive age.

All of the above points to the validity of an in-depth comprehensive study of postmenopausal adenomyosis in combination with pathological endometrial processes with the involvement of modern technologies.

The purpose of the work is to establish the role of steroid receptors in the pathogenesis of adenomyosis in the presence of concomitant endometrial pathology in postmenopausal women.

\section{Materials and methods}

As study material were used removed uterus with appendages from 117 patients 49-76 years old, who were
Table 1. Assessment of the intensity and spread of cell staining as a result of immunohistochemical reaction (points).

\begin{tabular}{|l|l|}
\hline \multicolumn{1}{|c|}{ Intensity } & \multicolumn{1}{c|}{ Distribution of staining } \\
\hline & $(0)$ - no stained cells \\
$0=$ absent & $(1)$ - stained cells are less than $1 / 100$ \\
$1=$ weak & $(2)$ - the number of stained cells from $1 / 100$ to $1 / 10$ \\
$2=$ intermediate & $(3)$ - the number of stained cells from $1 / 10$ to $1 / 3$ \\
$3=$ strong & $(4)$ - the number of stained cells from $1 / 3$ to $2 / 3$ \\
& $(5)$ - the number of stained cells is greater than $2 / 3$ \\
\hline
\end{tabular}

examined and treated at the Center for Reconstructive and Rehabilitation Medicine (University Clinic) of Odessa National Medical University for 2015-2018. Selection criteria - age (postmenopausal - no menstruation for more than a year) and a histologically verified diagnosis of adenomyosis. All cases are divided into 4 groups depending on the presence of $A M$ and on the background pathology (endometrioid endometrial carcinoma (ECE) and endometrial hyperplasia (EHP)): 1) 27 women with adenomyosis and EHP in endometrium; 2) 30 women with adenomyosis and ECE; 3) 30 women with adenomyosis and age-related changes in the endometrium; 4) 30 women with age-related changes without adenomyosis (comparison group).

Fragments of the test material were fixed in $10 \%$ neutral formalin $\mathrm{pH} 7.0$ for 24 hours at $37^{\circ} \mathrm{C}$. Immunohistochemical reaction was performed using primary antibodies: Estrogen Receptor (ER) clone SP1 (titer 1:400, LabVision Corporation, USA), Progesterone Receptor (PR) clone YR85 (titer 1:200, LabVision Corporation, USA), Androgen Receptor (AR) clone AR411 (titer 1:100, Dako, Denmark). The background staining was performed with Mayer's hematoxylin.

The result of immunohistochemical reactions was evaluated by a point system of continuous color method for the determination of ER-, PR-, AR-status according to D.C. Allred et al (1998) (Table 1). The total score was obtained by adding point of staining spread to intensity score. A score of 0 to 2 was considered ER-, PR-, AR-negative, a score > 2 was ER-, PR-, AR-positive.

The grouping, analysis and statistical processing of the obtained data were performed using parametric methods of variational statistics (arithmetic mean, mean error, confidence interval, Student's t-test) and the "Microsoft Office" programs.

\section{Results}

Immunohistochemical reactions with ER, PR, AR of the eutopic endometrium in the presence of EHP revealed certain features.

ER and PR showed high mean scores of intensity and prevalence of staining, unlike AR (Table 2). Epithelial cells of eutopic endometrium by EHP in more than a third (44.44 $\%$ ) of cases were characterized by predominance of ER activity over PR. In the stroma was observed the opposite situation with the predominance of PR over ER.

Immunohistochemical reaction of ER epithelial cells 


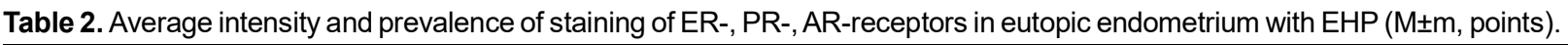

\begin{tabular}{|c|c|c|c|c|c|c|c|}
\hline \multirow{2}{*}{$\begin{array}{c}\text { Material of } \\
\text { research }\end{array}$} & \multirow{2}{*}{$\begin{array}{c}\text { Type of } \\
\text { receptor }\end{array}$} & \multicolumn{3}{|c|}{ Glandular component } & \multicolumn{3}{c|}{ Stromal component } \\
\cline { 3 - 8 } & & Intensity & Prevalence & Total score & Intensity & Prevalence & Total score \\
\hline \multirow{3}{*}{$\begin{array}{c}\text { Eutopic } \\
\text { endometrium }\end{array}$} & $\mathrm{ER}$ & $2.444 \pm 0.242$ & $4.889 \pm 0.120^{* *}$ & $7.333 \pm 0.314$ & $2.444 \pm 0.191^{* *}$ & $4.778 \pm 0.160$ & $7.148 \pm 0.276$ \\
\cline { 2 - 9 } & $\mathrm{PR}$ & $2.556 \pm 0.191^{*}$ & $4.593 \pm 0.189^{* * *}$ & $7.148 \pm 0.293$ & $2.815 \pm 0.149^{* * *}$ & $4.482 \pm 0.264^{*}$ & $7.296 \pm 0.369$ \\
\cline { 2 - 9 } & $\mathrm{AR}$ & $0.815 \pm 0.149$ & $1.222 \pm 0.283$ & $2.037 \pm 0.412$ & $0.704 \pm 0.176$ & $0.815 \pm 0.235$ & $1.519 \pm 0.397$ \\
\hline \multirow{3}{*}{$\begin{array}{c}\text { Ectopic } \\
\text { endometrium }\end{array}$} & $\mathrm{ER}$ & $1.815 \pm 0.315$ & $3.444 \pm 0.483$ & $5.148 \pm 0.745$ & $2.000 \pm 0.296$ & $3.482 \pm 0.383$ & $5.519 \pm 0.640$ \\
\cline { 2 - 9 } & $\mathrm{PR}$ & $2.148 \pm 0.250$ & $4.000 \pm 0.456$ & $6.148 \pm 0.676$ & $2.259 \pm 0.307$ & $4.000 \pm 0.347$ & $6.259 \pm 0.633$ \\
\cline { 2 - 9 } & $\mathrm{AR}$ & $0.333 \pm 0.181$ & $0.593 \pm 0.335$ & $0.926 \pm 0.512$ & $0.630 \pm 0.280$ & $0.630 \pm 0.280$ & $1.259 \pm 0.559$ \\
\hline
\end{tabular}

Notes: *- statistically significant differences in ER and PR scores between endometrial components in the group ( $p<0.05) ;{ }^{* *}$ - statistically significant differences in scores between ER and PR in the group $(p<0.05)$; ${ }^{* *}$ - statistically significant differences in scores, both between endometrial components and between ER and PR in the group $(p<0.05)$.

Table 3. Average intensity and prevalence of staining of ER-, PR-, and AR-receptors in eutopic endometrium with ECE (M $\pm m$, points).

\begin{tabular}{|c|c|c|c|c|c|c|c|}
\hline \multirow{2}{*}{$\begin{array}{c}\text { Material of } \\
\text { research }\end{array}$} & \multirow{2}{*}{$\begin{array}{c}\text { Type of } \\
\text { receptor }\end{array}$} & \multicolumn{3}{|c|}{ Glandular component } & \multicolumn{3}{c|}{ Stromal component } \\
\cline { 3 - 8 } & & Intensity & Prevalence & Total score & Intensity & Prevalence & Total score \\
\hline \multirow{3}{*}{$\begin{array}{c}\text { Eutopic } \\
\text { endometrium }\end{array}$} & $\mathrm{ER}$ & $2.367 \pm 0.318^{*}$ & $3.833 \pm 0.421^{*}$ & $6.200 \pm 0.712^{*}$ & $1.400 \pm 0.291^{* * *}$ & $2.767 \pm 0.348^{* * *}$ & $4.167 \pm 0.602^{* * *}$ \\
\cline { 2 - 8 } & $\mathrm{PR}$ & $2.379 \pm 0.293$ & $4.000 \pm 0.394$ & $6.40 \pm 0.656$ & $2.069 \pm 0.301^{* *}$ & $3.552 \pm 0.474^{* *}$ & $5.571 \pm 0.782^{* *}$ \\
\cline { 2 - 8 } & $\mathrm{AR}$ & $0.567 \pm 0.224$ & $0.767 \pm 0.348$ & $1.333 \pm 0.619$ & $0.567 \pm 0.180$ & $0.900 \pm 0.343$ & $1.467 \pm 0.504$ \\
\hline \multirow{3}{*}{$\begin{array}{c}\text { Ectopic } \\
\text { endometrium }\end{array}$} & $\mathrm{ER}$ & $1.667 \pm 0.237$ & $3.000 \pm 0.339^{*}$ & $4.667 \pm 0.526^{*}$ & $1.433 \pm 0.243^{* *}$ & $2.367 \pm 0.493^{* * *}$ & $3.857 \pm 0.621^{* * *}$ \\
\cline { 2 - 9 } & $\mathrm{PR}$ & $2.000 \pm 0.345$ & $3.310 \pm 0.507$ & $5.300 \pm 0.809$ & $1.931 \pm 0.344^{* *}$ & $3.241 \pm 0.530^{* *}$ & $5.32 \pm 0.849^{* *}$ \\
\cline { 2 - 9 } & $\mathrm{AR}$ & $0.500 \pm 0.205$ & $0.900 \pm 0.368$ & $1.367 \pm 0.598$ & $0.867 \pm 0.155$ & $1.400 \pm 0.359$ & $2.267 \pm 0.479$ \\
\hline
\end{tabular}

Notes: *- statistically significant differences in ER and PR scores between endometrial components in the group $(p<0.05)$; ${ }^{* *}$ - statistically significant differences in scores between ER and PR in the group $(p<0.05)$; ${ }^{* * *}$ - statistically significant differences in scores, both between endometrial components and between ER and PR in the group $(p<0.05)$.

had the highest rates in the centers of adenomyosis with simple EHP without atypia (Fig. 1).

There were no differences in the expression of ER and PR between the components of the ectopic endometrium and between the receptors. AR expression is absent in one third of cases with adenomyosis and EHP. Analysis of the ratio of ER and $P R$ in ectopic endometrium revealed an advantage of expression of PR over ER in more than $40 \%$ of cases.

Among women with G1 ECE, there were more frequent cases with high levels of ER cell gland expression. An opposite situation was observed with G3 ECE, with minimal scores of ER epithelial cell expression.

A similar situation with the expression of ER epithelial cells was observed in the determination of PR expression: maximum indicators of receptor activity - most often for $\mathrm{G} 1$ ECE, moderate - for G2 ECE, minimum - for G3 ECE. The latter in some places was characterized by complete absence of immunohistochemical reaction.

The average total ER expression score was not significantly different from such PR (Table 3 ). AR expression had minimal intensity and color prevalence scores. The study found that the normal distribution of ER and PR, that is, in which the ratio of ER and PR goes to 1, in the glandular component of the eutopic endometrium is present in 13 $(43.33 \%)$ women, and in the stromal - only in $8(26.67 \%)$. In $16(53.33 \%)$ cases in the stroma, a decrease in ER was observed against the background of an increase in PR $(E R / P R<1)(p<0.05)$.

In the ectopic epithelium of ECE, higher scores of ER expression were observed for G1 ECE and minimal and, wherever, complete absence of immunohistochemical reaction for G3 ECE. PR had the highest levels of receptor activity compared to other receptors (Fig. 2).

In the group of patients with adenomyosis and ECE in

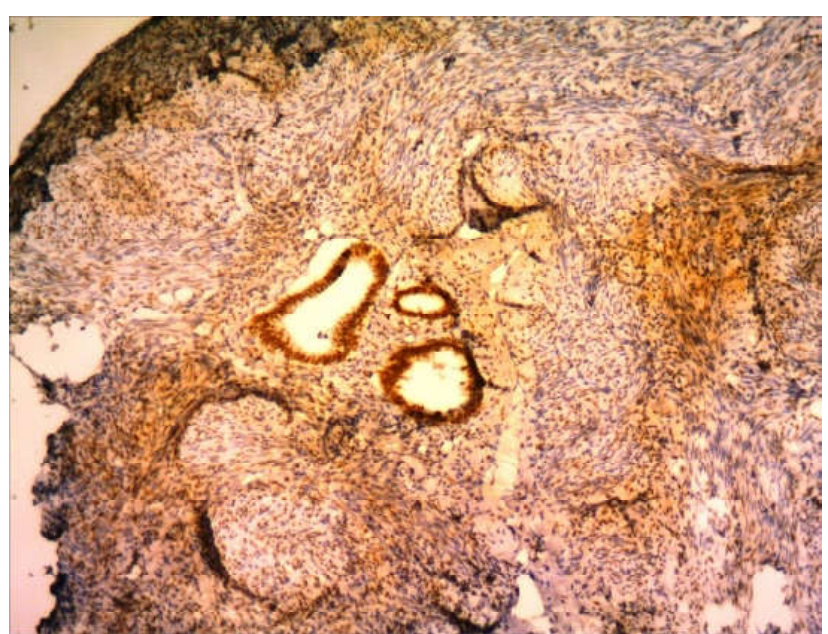

Fig. 1. Area of AM female 64 years old with simple EHP without atypia. Expressed IGC reaction (+++) cells glandular (3/5) and stromal components (3/4). IGC reaction to estrogen markers. $x 100$. 


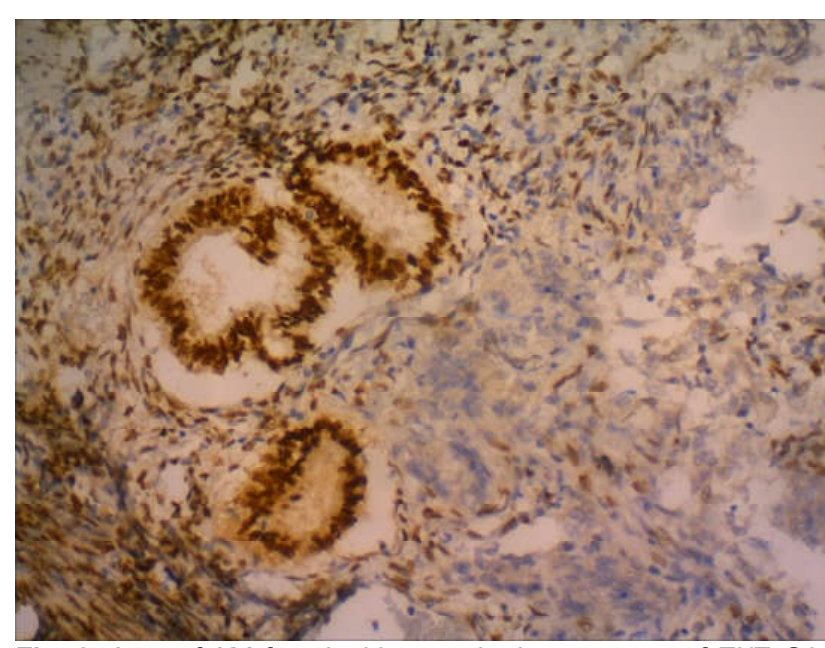

Fig. 2. Area of AM female 66 years in the presence of EKE G2. Pronounced IGC reaction (+++) cells glandular (3/5) and moderate (++) stromal (2/4) components. IGC reaction to estrogen markers. X200.

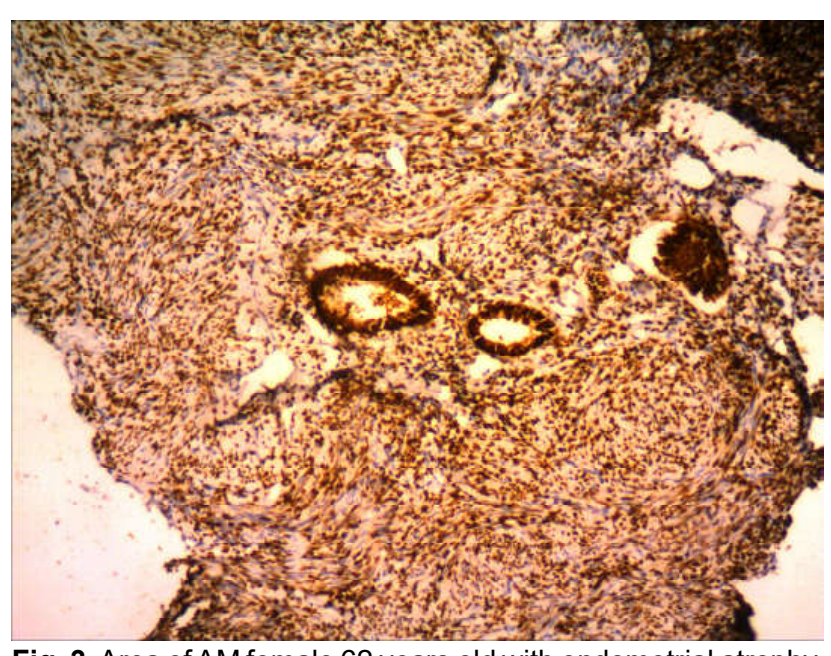

Fig. 3. Area of AM female 62 years old with endometrial atrophy. Expressed IGC reaction (+++) cells of the glandular (3/5) and stromal $(3 / 5)$ components. IGC reaction to markers of progesterone. $x 100$.

Table 4. Average intensity and prevalence of staining of ER-, PR-, AR-receptors in eutopic endometrium with atrophy (M $\pm m$, points).

\begin{tabular}{|c|c|c|c|c|c|c|c|}
\hline \multirow{2}{*}{$\begin{array}{c}\text { Material of } \\
\text { research }\end{array}$} & \multirow{2}{*}{$\begin{array}{c}\text { Type of } \\
\text { receptor }\end{array}$} & \multicolumn{4}{|c|}{ Glandular component } & \multicolumn{3}{c|}{ Stromal component } \\
\cline { 3 - 8 } & & Intensity & Prevalence & Total score & Intensity & Prevalence & Total score \\
\hline \multirow{3}{*}{$\begin{array}{c}\text { Eutopic } \\
\text { endometrium }\end{array}$} & $\mathrm{ER}$ & $1.467 \pm 0.244$ & $2.967 \pm 0.544$ & $4.433 \pm 0.773$ & $1.700 \pm 0.328$ & $2.833 \pm 0.432$ & $4.567 \pm 0.738$ \\
\cline { 2 - 8 } & $\mathrm{PR}$ & $1.800 \pm 0.317$ & $3.367 \pm 0.613$ & $5.167 \pm 0.907$ & $2.000 \pm 0.364$ & $3.467 \pm 0.585$ & $5.467 \pm 0.943$ \\
\cline { 2 - 8 } & $\mathrm{AR}$ & $0.367 \pm 0.175$ & $0.767 \pm 0.406$ & $1.133 \pm 0.570$ & $0.667 \pm 0.368$ & $0.667 \pm 0.4368$ & $1.33 \pm 0.736$ \\
\hline \multirow{3}{*}{$\begin{array}{c}\text { Ectopic } \\
\text { endometrium }\end{array}$} & $\mathrm{ER}$ & $1.233 \pm 0.384^{* *}$ & $2.200 \pm 0.700^{* *}$ & $3.433 \pm 1.074^{* *}$ & $1.700 \pm 0.341^{* *}$ & $2.733 \pm 0.469^{* *}$ & $4.433 \pm 0.790^{* *}$ \\
\cline { 2 - 8 } & $\mathrm{PR}$ & $2.200 \pm 0.288^{* *}$ & $3.967 \pm 0.425^{* *}$ & $6.167 \pm 0.704^{* *}$ & $2.400 \pm 0.276^{* *}$ & $3.733 \pm 0.338^{* *}$ & $6.167 \pm 0.595^{* *}$ \\
\cline { 2 - 9 } & $\mathrm{AR}$ & $0.333 \pm 0.172$ & $0.667 \pm 0.391$ & $1.0 \pm 0.548$ & $0.967 \pm 0.318$ & $1.400 \pm 0.511$ & $2.367 \pm 0.816$ \\
\hline
\end{tabular}

Notes: ${ }^{* *}$ - statistically significant differences in scores between ER and PR in the group $(p<0.05)$.

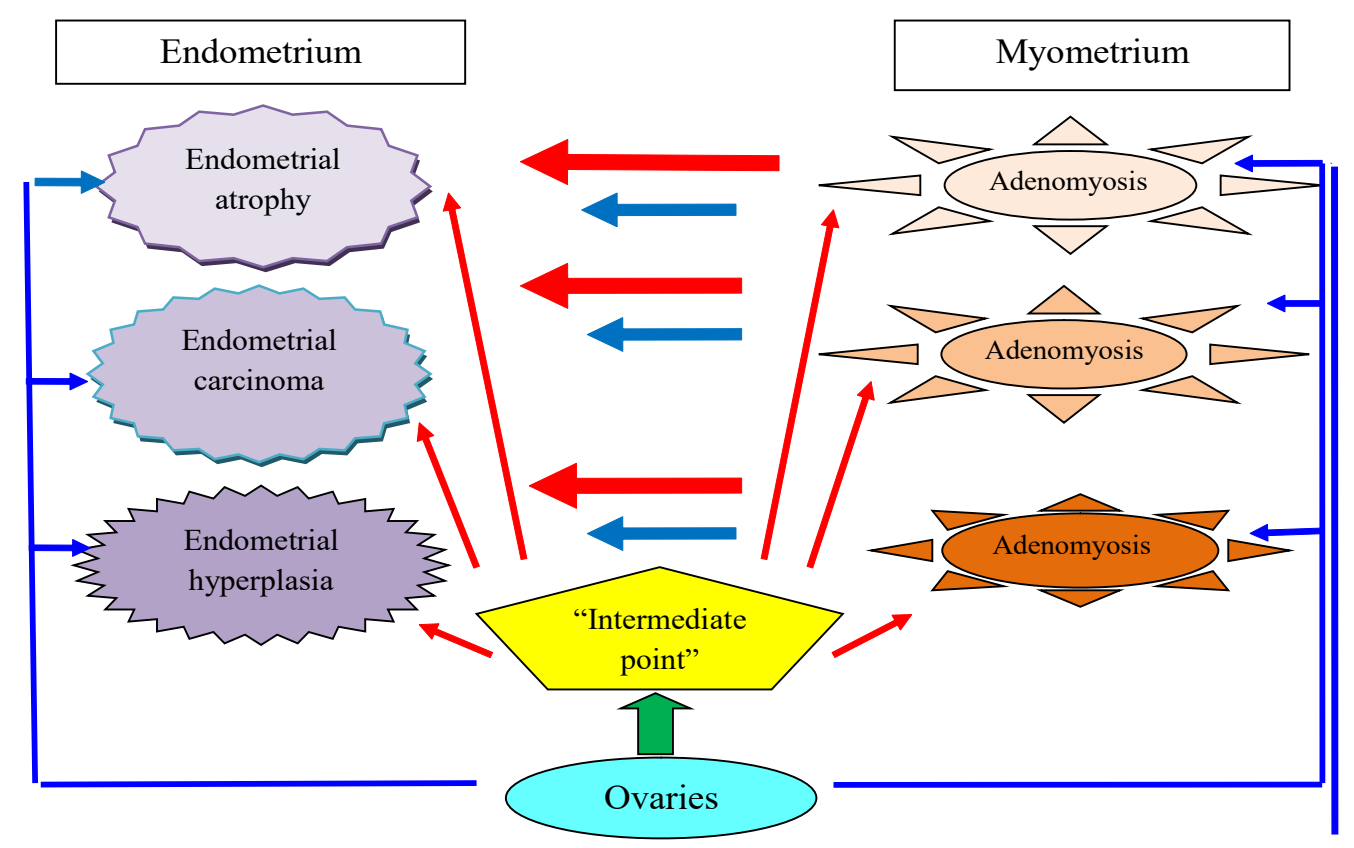

Estrogen influence

Progesterone influence

Androgenic influence.

Fig. 4. Scheme of pathogenesis of adenomyosis in postmenopausal women. 
Table 5. Average intensity and prevalence of staining of ER-, PR-, and AR-receptors in endometrium with age-related changes (M $\pm m$, points).

\begin{tabular}{|c|c|c|c|c|c|c|}
\hline \multirow{2}{*}{$\begin{array}{c}\text { Type of } \\
\text { receptor }\end{array}$} & \multicolumn{3}{|c|}{ Glandular component } & \multicolumn{3}{c|}{ Stromal component } \\
\cline { 2 - 7 } & Intensity & Prevalence & Total score & Intensity & Prevalence & Total score \\
\hline ER & $0.967 \pm 0.318$ & $1.567 \pm 0.577$ & $2.533 \pm 0.885$ & $0.767 \pm 0.261$ & $1.500 \pm 0.513$ & $2.267 \pm 0.757$ \\
\hline PR & $1.100 \pm 0.391$ & $1.900 \pm 0.589$ & $3.000 \pm 0.968$ & $1.000 \pm 0.282$ & $2.100 \pm 0.590$ & $3.100 \pm 0.858$ \\
\hline AR & $0.833 \pm 0.327$ & $1.37 \pm 0.598$ & $2.200 \pm 0.918$ & $0.533 \pm 0.308$ & $0.667 \pm 0.431$ & $1.200 \pm 0.718$ \\
\hline
\end{tabular}

the stroma, there is a higher level of PR expression than $E R$, in contrast to the glandular component (Table 3). Immunohistochemical reaction with $A R$ in glandular cells was more often absent, in stroma - had minimal indicators of receptor expression. All patients showed a predominance of ER over PR in the stroma of endometrioid heterotopias $(p<0.05)$.

There were no differences in the expression of ER and $\mathrm{PR}$ in the group with AM and endometrial atrophy between the components of the eutopic and between the receptors themselves (Table 4). The intensity and prevalence of AR coloration in most women were zero.

In 19 (63.33\%) women of group III in epithelial cells of eutopic endometrium the predominance of the ratio ER/ $P R=1(p<0.05)$ was established. In the stroma, there was a more frequent decrease in $E R$ relative to $P R(E R / P R<1)$ $(p<0.05)$.

In ectopic endometrium in atrophy in one third of women with IGC, the response of ER glandular cells was absent. Immunohistochemical reaction of PR in more than one third of cases was evaluated in maximum parameters (Fig. 3 ), unlike AR. The prevalence of PR expression over ER in the foci of adenomyosis was established $(p<0.05)$ (Table 4).

The glandular component of the ectopic endometrium in most women was characterized by an increase in $P R$ and a decrease in ER $(E P / P R<1)(p<0.05)$. A similar pattern with a predominance of $P R$ was also found in stroma cells $(p<0.05)$ (Fig. 4).

Immunohistochemical study of the receptor apparatus of glandular and stromal cells of the endometrial women of the comparison group to markers ER, PR and AR revealed minimal scores in both intensity and prevalence of staining (Table 5).

\section{Discussion}

Speaking about the overall picture of the results of the study, postmenopausal patients are characterized by differences in the expression levels of ER, PR, and AR not only between the components of the eu- and ectopic endometrium of the respective groups, but also between the groups themselves.

The presence of high rates of ER activity in endometrial components of EHP confirms the role of hyperestrogenemia in the pathogenesis of EHP. Endometrial cell proliferation is facilitated by long-term estrogen exposure $[1,7,8,17$, 21]. The steroid dependence of endometrial glandular cells on EHP is undeniable. Stromal cells also exhibit positive ER activity, as confirmed by the work of other scientists [7, 11, 21].

The highest rates of ER expression in the stroma of the eutopic endometrium with EHP were observed in simple and complex forms of EHP without atypia. Atypical immunohistochemical reaction was less pronounced and was accompanied by a decrease in ER expression, indicating a violation of their reception. According to V.O. Beniuk and co-authors (2013), decrease in the level of activity of the receptor apparatus indicates the worsening of the pathological process and the likelihood of further malignancy [7]. According to the works of Tumansky V.O. and Baudarbekova M.M. (2009), pronounced ER activity was found in non-atypical EHP, moderate and weak in atypical EHP [21]. The opposite is the opinion of Z.V. Chumak et al (2014): atypical EHP is characterized by higher ER expression results than non-atypical EHP. However, all of the above results were relevant for women of predominantly reproductive and premenopausal age [11].

Analysis of the results of estrogen receptor expression in eutopic endometrium with endometrioid endometrial carcinoma revealed an increase in receptor activity from G3 to G1 ECE, which is in line with the O.A. Samsonova data (2004) on the more frequent detection of estrogen and progesterone receptors in highly differentiated endometrial tumors and a decrease in their activity and quantity in accordance with a decrease in the degree of cell differentiation [20]. Decrease in the expression of ER, or lack thereof, indicate a loss of regulatory effect of estrogen hormones and autonomic growth of the tumor process [8, 22].

Positive expression of ER eutopic endometrium was detected in the presence of atrophy and adenomyosis, which indicates the preservation of receptor activity and regulatory influence of postmenopausal estrogens in the absence of hyperplastic processes in the endometrium.

Analysis of the results of immunohistochemical reactions in the endometrium of women in the comparison group showed low hormonal dependence of endometrial components, as indicated by the minimal scores of ER expression of glandular and stromal cells.

The study found a predominance of the expression level of ER in the glandular and stromal components of the eutopic endometrium in the presence of adenomyosis and hyperplastic processes compared with the comparison 
group $(p<0.01)$. The obtained data partly correspond to the results of other scientists. So, V.O. Beniuk et al. (2013), although it is claimed that the content of ER in epithelial cells of endometrium with EHP is higher than in women without the specified pathology, but in the stroma of reliable differences scientists have not established [7]. The presence of lower intensity scores and the spread of ER staining in the stromal component, compared with the glandular $(p<0.05)$, indicates an uneven effect of the same hormones on the respective structures and their different hormonal dependence. Tumansky V.O. and Chepetz A.V. (2016) holds the same opinion., indicating a decrease in ER expression in stroma cells compared with gland cells [22].

The results show that higher expression of ER is characteristic of epithelial cells in endometrium with EHP (7.333 \pm 0.314 points) and ECE $(6.200 \pm 0.712$ points) than in endometrium with atrophic changes in the presence of adenomyosis (4.433 \pm 0.773 points). In stromal cells, higher ER activity rates were detected by EHP $(7.148 \pm 0.276$ points) compared to endometrium with atrophic changes (4.567 \pm 0.738 points) and ECE (4.167 \pm 0.602 points).

Positive immunohistochemical reaction from ER components of endometrioid heterotopias in postmenopausal women indicates the hormonal dependence of pathological foci and the key role of steroid hormones in the development and conservation of foci of adenomyosis. The study found positive overall cumulative ER reception in all groups of women with adenomyosis. R.A. Akopyan and V.A. Pechenikova (2014), O.G. Kuryk and O.V. Kalenska (2014) indicated positive expression of ER in endometrioid foci $[4,18]$. Some authors have suggested that estrogen levels increase locally in postmenopausal women with internal endometriosis, but these studies have addressed patients with isolated pathology - adenomyosis [4]. Other scientists have emphasized the leading role in the development of "hyperplastic syndrome" (EHP, adenomyosis and uterine fibroids) of local hyperestrogenemia, not balanced by hyperprogesteronemia [17]. Local hyperestrogenemia may be the result of local hormone synthesis, indicating the autonomy of endometrioid foci [7].

It was found that in the glandular component of internal endometriosis foci, lower ER expression was observed in atrophy (3.433 \pm 1.074 points) compared to foci of adenomyosis in endometrioid carcinoma $(4.667 \pm 0.526$ points) and endometrial hyperplasia $(5.148 \pm 0.745)$. In endometrioid heterotopy stroma, estrogen receptor expression is higher in hyperplasia than in endometrioid endometrial carcinoma and atrophy.

When comparing the results of the expressive activity of the steroid receptors of the eu- and ectopic endometrium, no differences were found ( $p>0.05$ ), except for the group of women with adenomyosis and EHP. The data obtained differ with the findings of some studies, according to which the level of ER in the traces of endometrioid heterotopias is lower than in eutopic endometrium [7, 30]. Patients with adenomyosis and endometrial hyperplasia have a predominance of ER expression over PR in eutopic endometrium $(p<0.01)$. This situation can be explained as follows: endometrioid foci have some estrogenic potential, which in turn affects the eutopic endometrium. Such dependence is confirmed by the fact of lower expressive ER activity in the endometrium of the comparison group relative to the eutopic endometrium in the group of patients with atrophy and adenomyosis, both in the stroma and in the glands. The following pattern is interesting: the higher the estrogenic potential of the eutopic endometrium, the higher the ER expression in endometrioid foci. This phenomenon is well evident in the group with endometrioid endometrial carcinoma, since in this group there were patients, depending on the level of cell differentiation, with both high and low estrogen receptor expression scores in the eutopic endometrium. The higher the level of differentiation of ECE cells, the higher was the estrogenic activity in the endometrium of ECE and in the focuses of internal endometrosis. This is evidenced by higher scores of ER expression in AM focuses on EHP than in atrophy, in which the eutopic endometrium has lower estrogen activity rates.

The cells of the components of the eu- and ectopic endometrium have estrogenic and progesterone activity, which coincides with the conclusions reached in their work in 2014 by R.A. Hakobyan and V.A. Pechenikova, and O.G. Kuryk and O.V. Kalenskaya [4, 18]. Progesterone receptors have no less activity than estrogen in endometrium with endometrial hyperplasia, and, in some cases, even greater [21]. The activity of PR decreases from simple non-atypical to complex atypical EHP [11].

In patients with adenomyosis and endometrioid carcinoma of the endometrium observed a similar pattern with the expression of $P R$, as for estrogen receptors: as the degree of differentiation of ECE cells (from G1 to G3 ECE) decreased the receptor activity of progesterone receptors. Reduction of PR expression or their absence in ECE cells V.A. Tumansky and A.V. Chepetz in 2016 explained the loss of regulatory influence of steroid hormones and the autonomy of tumor growth [22].

In the comparison group, minimal PR expression indicated low hormonal dependence of endometrial components in women without adenomyosis and postmenopausal endometrial hyperplastic processes.

Positive PR expression in internal endometriosis cells was found in groups of women with adenomyosis, which proves their hormonal dependence and the key role of these hormones in the existence of postmenopausal focuses of adenomyosis. It is possible that this is a consequence of the local synthesis of progesterone hormones in endometrioid foci [4]. Cases with low activity and moderate expression of PR are associated with a decrease in progesterone dependence.

When comparing the expression scores of steroid receptors of the eu- and ectopic endometrium, no differences were found between the indices $(p>0.05)$. An exception was women with adenomyosis and EHP, which was dominated 
by expression of progesterone receptors in eutopic endometrial cells over ectopic $(p<0.01)$. Thus, the results obtained are partly consistent with the findings of some scientists, according to which the level of progesterone receptors in the foci of adenomyosis is lower than in the eutopic endometrium [4, 30].

The preservation of the expression of the PR foci of postmenopausal adenomyosis in both epithelial and stromal cells was confirmed, regardless of concomitant pathology. However, there were no significant differences between the mean total PR expression scores in the stroma of ectopic foci. This indicates the absence of regularities between the expression levels of PR eu- and ectopic endometrium, depending on the level of cell differentiation inherent in estrogen receptors. It should be noted that PR activity differed in eutopic endometrium depending on the presence of internal endometriosis. Patients with atrophy and adenomyosis had higher progesterone receptor expression scores in eutopic endometrium than the comparison group women. Endometrioid foci may have a regulatory effect on eutopic endometrium, with some progesterone potential. However, they remain independent of the eutopic endometrial feedback.

When comparing the expression of ER and PR revealed both the normal ratio of ER and PR, and the predominance of ER over PR, as evidenced by the presence of only 2 phenotypic variants of the distribution of receptors ER and $P R$ : $E R>P R$ and $E R=P R$. The advantage of ER over $P R$ in non-atypical EHP in their study was established by V.O. Tumansky and M.M. Baudarbekova (2009) [21]. According to the work of V.O. Beniuk and V.M. Goncharenko (2013), just enough receptors for progesterone and maintaining a normal ratio of ER and PR, which goes to 1, provides sensitivity of the endometrium with EHP to progestin therapy [8]. Thus, not only hyperestrogenemia, but also hyperprogesteronemia and maintaining the appropriate ratio of ER and PR are important in the pathogenesis of simple atypical EHP. Therefore, not only the ER but also the level of PR plays a leading role in proliferative processes in the endometrium. The transition of the non-atypical form to the atypical one is accompanied not only by a decrease in the sensitivity of the receptor apparatus, but also by the predominance of progesterone receptors over estrogenic ones.

The presence of more than $60 \%$ of women with adenomyosis and atrophy in epithelial cells in the eutopic endometrium of a normal ratio of ER and $P R$, which went to $1(p<0.05)$, indicates that the condition of the existence of glandular elements of eutopic endometrium with adenomyosis and without hyperplastic processes are to maintain a balance between ER and PR. The situation is different when was observed in stromal cells: in most cases there was a decrease in estrogen receptors against a background of progesterone increase $(E R / P R<1)(p<0.05)$. This indicates the advantage of progesterone exposure.

In the group of women with adenomyosis and ECE it was found that the stroma showed higher expression of PR than ER $(p<0.05)$. This indicates a greater regulatory effect of progesterone receptors than estrogen receptors. It was in the stroma of the endometrium with ECE that a decrease in ER was observed against the background of an increase in $P R(E R / P R<1)(p<0.05)$. In the epithelial cells of the ectopic endometrium, ECE was dominated by a balanced variant of the ratio $E R$ and $P R(E R=P R)(p<0.05)$. Higher $P R$ expression in the stroma demonstrates progesterone dependence of endometrioid heterotopia cells and indicates its superiority over estrogen. This is confirmed by the smaller number of cases $(6.67 \%)$ with the phenotypic variant of receptor distribution in the stroma foci AM - ER/PR>1 $(p<0.05)$. Other scientists point to the positive expression of $P R$ in endometrioid heterotopias in women of both reproductive and menopausal periods $[4,18,19]$.

In women with adenomyosis and endometrial atrophy the opposite situation was observed: in endometrioid foci, the expression of PR was higher than ER $(p<0.05)$, and in most cases there was a phenotypic variant of the ratio of receptors with a predominance of PR over ER $(E P / P R<1)$ $(p<0.05)$. Therefore, for postmenopausal adenomyosis pathogenetically important is the advantage of progesterone influence over estrogen.

Different levels of receptors under study at foci of adenomyosis result from different hormonal dependence of endometrioid focus cells. For the development and existence of internal endometriosis in postmenopausal sufficient estrogen and progesterone effects are required. The implementation of the cellular response is a consequence of the interaction of the hormone and the corresponding receptor. In postmenopausal conditions, a sufficient number of hormones can be synthesized locally, in the foci of adenomyosis, against the background of the ovarian function. However, it should not be forgotten that in groups of women, adenomyosis "coexisted" with EHP and ECE, whose endometrium had some hormonal potential and receptor activity. Therefore, in the pathogenesis of postmenopausal adenomyosis, local estrogen and progesterone activities of constituent ectopic foci play a leading role.

The study obtained minimal indicators, and sometimes complete absence, of AR receptor expression in the euand ectopic endometriums, which indicates that there is no direct regulatory effect on the development of androgen adenomyosis. However, despite this, AR expression in stromal ECE is higher in focal endometriosis foci than in eutopic endometrium $(p<0.05)$. In the analysis of the activity of AR differences between the expression levels in the eutopic endometrium of the studied groups of women were not found, which suggests that the androgenic potential of foci of adenomyosis and their influence on the level of AR in the eutopic endometrium is absent.

Evaluation of the results of AR expression in ectopic endometrium showed the presence of lower rates of AR expression in the stroma of endometrioid foci on EHP 
compared with other patients in the study group $(p<0.05)$. However, the level of AR activity in all study groups was minimal.

Some researchers, studying the peculiarities of the existence of post-menopausal EHP, argue that this is possible in the presence of hormone-active structures in the ovaries and extra-gonad synthesis of estrogens in adipose tissue or inflammatory processes of the endometrium and appendages of the uterus [12]. Since the leading role in the pathogenesis of adenomyosis and EHP is played by local hyperestrogenemia, these pathological conditions can cause the development of adenomyosis. Given the possibility of estrogen synthesis in focal endometriosis foci, endometrioid heterotopias can be considered as an autonomous lesion of the myometrium and a source of estrogen synthesis for eutopic endometrium. This hypothesis is confirmed by the presence of higher rates of ER expression in eutopic endometrium in the presence of adenomyosis, including atrophic changes than in women without adenomyosis. The absence of estrogenic potential of the ovaries in postmenopausal women, positive expression of ER in the eu- and ectopic endometriums may indicate the existence of an "intermediate point" of estrogen synthesis. In the future, the estrogens synthesized at such an intermediate point are sent to the eu- and ectopic endometrium. Estrogens that have reached the foci of adenomyosis potentiate greater estrogen production in endometrioid heterotopias. Subsequently, some of the estrogens remain in the focuses of adenomyosis, and some go to the eutopic endometrium. Thus, the hormonal theory of the pathogenesis of adenomyosis, which is the basis of hyperestrogenia, is inferior to the theory of hormonal metabolism disorders, based on impaired sensitivity of

\section{References}

[1]Adamyan, L. V., Andreeva, E. N., Apolikhina, I. A., Balan, V. E., Bezhenar, V. F., Gevorkyan, M. A., \& Torubanov, S. F. (2015). Combined benign tumors and hyperplastic processes of the uterus (myoma, adenomyosis, hyperplasia, endometritis). Retrieved from: http://www.mediexpo.ru>contect>pdf.

[2] Agarwal, S., Alzahrani, F.A., \& Ahmed, A. (2018). Hormone Replacement Therapy: Would it be Possible to Replicate a Functional Ovary? Int. J. Mol. Sci., 19(10), 3160. doi: 10.3390/ ijms19103160.

[3] Agostinho, L., Cruz, R., Osório, F., Alves, J., Setúbal, A., \& Guerra, A. (2017). MRI for adenomyosis: a pictorial review. Insights Imaging, 8(6), 549-556. doi: 10.1007/s13244-0170576-z.

[4] Akopian, A. R., \& Pechenikova, V. A. (2014). Clinical and morphological features of adenomyosis in women of various age groups. Bulletin of the Russian Military Medical Academy, 45(1), 65-70

[5] Afinogenova, E. A., \& Cherstvyy, Ye. D. (2016). Active and inactive adenomyosis: a comparative analysis in the eyes of the ectopic endometrium (expression of aromatase P-450, estrogen receptors $A$ and $B$, progesterone receptors). Bulletin of education and development of science of the Russian Academy of Natural Sciences, 20(2), 74-82. hormone-dependent tissues to the influence of steroids and pronounced imbalance of estrogens, progesterone and androgens.

To summarize, we can propose the following concept of pathogenesis of postmenopausal adenomyosis. Estrogens, formed at the "intermediate point" of androgens, affect the eu- and ectopic endometrium. Endometrioid foci (as an autonomous system), in turn, stimulate the presence of positive estrogen and, to a lesser extent, progesterone expression in the eutopic endometrium (Fig. 4).

Prospects for further development are to study the eutopic endometrium and foci of internal endometriosis of the expression of P-450 aromatase, as a possible key enzyme under which the formation of estrogens from androgens takes place.

\section{Conclusions}

1. Higher levels of differentiation of eutopic endometrial cells correspond to higher estrogenic activity of eu- and ectopic endometrium. Focuses of adenomyosis affect the eutopic endometrium, stimulating the activity of ER.

2. Endometrioid foci exert a regulatory effect on eutopic endometrium in the form of PR stimulation. Adenomyosis foci remain independent of the eutopic endometrium feedback.

3. The absence of androgenic potential of foci of adenomyosis and their influence on the level of $A R$ in eutopic endometrium were revealed.

4. We suggest to consider endometrioid foci as an autonomous source of production of estrogen and progesterone hormones. Adenomyosis foci stimulate the presence of positive estrogen and, to a lesser extent, progesterone expression in the eutopic endometrium.

[6]Aznaurova, Y. B., Zhumataev, M. B., Roberts, T. K., Aliper, A. M., \& Zhavoronkov, A. A. (2014). Molecular aspects of development and regulation of endometriosis. Reprod. Biol. Endocrinol., 12, 50. doi: 10.1186/1477-7827-12-50.

[7] Beniuk, V. A., Vinyarski, Y. M., Goncharenko, V. M., Kalenska, O. V., \& Ponomarchuk, R. M. (2013). Diagnostic significance of determining the expression of hormone receptors and apoptosis markers in endometrial hyperplastic processes. Health of the nation, 3(27), 14-20.

[8] Beniuk, V. O., \& Goncharenko, V. M. (2014). Individualization of treatment of women of reproductive and premenopausal age with endometrial hyperplastic processes. Woman's health, 10(96), 125-129. Retrieved from: http://nbuv.gov.ua/UJRN/ Zdzh_2014_10_33

[9] Bodur, S., Dundar, O., Pektas, M. K., Babayigit, M. A., Ozden, O., \& Kucukodaci, Z. (2015). The clinical significance of classical and new emerging determinants of adenomyosis. Int. J. Clin. Exp. Med., 8(5), 7958-7964.

[10] Caixia, J., Chao, L., Jing, G., Li, C., Ning, L., Xiaoyan, Q., \& Zhongping, C. (2017). The Expression of Toll-like receptors in eutopic and ectopic endometrium and its implication in the inflammatory pathogenesis of adenomyosis. Sci. Rep., 7, 7365. doi: 10.1038/s41598-017-07859-5. 
[11] Chumak, Z. V., Zelinsky, A. A., Shapoval, N. V., Shapoval, N. V., \& Isterin, N. S. (2014). Assessment of hormonal-receptor status and proliferative activity of hyperplastic endometrium. Odessa Medical Journal, 142(2), 66-70. Retrieved from: http:/ Inbuv.gov.ua/UJRN/Omj_2014_2_17

[12] Divakova, T. S., \& Medvedskaya, S. E. (2006). Management of patients with recurrent endometrial hyperplasia in peri- and postmenopausal women. Bulletin of Vitebsk State Medical University, 5(3), 75-79. Retrieved from: http://elib.vsmu.by/ handle/123/8845

[13] Eun, L. C., Seong, B. C., Sa, R. L., Young, M. L., Kyungah, J., Hye-Sung, M., \& Hyewon, C. (2017). Comorbidity of gynecological and non-gynecological diseases with adenomyosis and endometriosis. Obstetr. Gynecol. Sci., 60(6), 579-586. doi: 10.5468/ogs.2017.60.6.579.

[14] Garavaglia, E., Serafini A., Inversetti, A., Ferrari, S., Tandoi, I., Corti, L., \& Candiani, M. (2015). Adenomyosis and its impact on women fertility. Iran J. Reprod. Med., 13(6), 327-336. Retrieved from: https://www.ncbi.nlm.nih.gov/pmc/articles/ PMC4555051/

[15] Gemmell, L. C., Webster, K. E., Kirtley, S., Vincent, K., Zondervan, K. T., \& Becker, C. M. (2017). The management of menopause in women with a history of endometriosis: a systematic review. Hum Reprod Update, 23(4), 481-500. doi: 10.1093/humupd/dmx011.

[16] Gizzo, S., Patrelli, T. S., Dall'asta, A., Di Gangi, S., Giordano, G., Migliavacca, C., \& Berretta, R. (2016). Coexistence of adenomyosis and endometrioid endometrial cancer: Role in surgical guidance and prognosis estimation. Oncol. Lett., 11(2), 1213-1219. doi:10.3892/ol.2015.4032

[17] Kudrina, E. A., Zholobova, M. N., \& Masyakina, A. V. (2016). Modern aspects of the pathogenesis and treatment of endometrial hyperplasia, uterine fibroids and adenomyosis. Archive of Obstetrics and Gynecology named after V.F. Snegireva, 3(3), 131-135. doi: 10.18821/2313-8726-2016-33-130-135

[18] Kurik, O. G. \& Kalenska, O. V. (2014). Immunologic hormonal activity of ectopic and eutopic endometria with adenomyosis. Scientific journal of the Ministry of Health of Ukraine, 1(5), 100-105. Retrieved from: http://nbuv.gov.ua/UJRN/ njmoz_2014_1_16

[19] Meliksetian, A. V., Kuryk, O. G., Kalenskaya O. V. \& Lysenko B. M. (2014). Immunohistochemical study of estrogen and progesterone receptors in foci of genital endometriosis. Ukrainian scientific-medical youth journal, 3(82), 71-73.

[20] Pozharisski, K. M., Vinokurov, V. L., Zharinov, G. M., Boldaryan,
N. A., Kuznetsova, M. Ye., Gasparyan, N. A., \& Samsonova, Ye. A. (2008). Immunohistochemical markers as prognosticators in oncogynecology. Problems in Oncology, 54(4), 463-470. ISSN: 0507-3758.

[21] Tumansky, V. A., \& Baudarbekova, M. M. (2009). Study of estrogen and progesterone receptors in glandular hyperplasia, atypical hyperplasia and endometrial adenocarcinoma. Pathology, 6(2), 111-113. Retrieved from: http://nbuv.gov.ua/ UJRN/pathology_2009_6_2_31

[22] Tumansky, V. A. \& Chepets, A. V. (2016). Comparative immunohistochemical characterization of the expression of estrogen-? and progesterone receptors, p16 and p53, Ki-67 and caspase 3 in invasive endometrioid adenocarcinoma of the uterus and in proliferative endometrium. Pathology, 1(36), 22-28. DOI: 10.14739/2310-1237.2016.1.72165

[23] Rižner, T. L. (2009). Estrogen metabolism and action in endometriosis. Mol. Cell. Endocrinol., 307(1-2), 8-18. doi: 10.1016/j.mce.2009.03.022.

[24] Rižner, T. L. (2016). The Important Roles of Steroid Sulfatase and Sulfotransferases in Gynecological Diseases. Front. Pharmacol., 7, 30. doi: 10.3389/fphar.2016.00030.

[25] Taran, F. A., Stewart, E. A., \& Brucker, S. (2013). Adenomyosis: Epidemiology, Risk Factors, Clinical Phenotype and Surgical and Interventional Alternatives to Hysterectomy. Geburtshilfe Frauenheilkd, 73(9), 924-931. doi: 10.1055/s-0033-1350840.

[26] Tetikkurt, S., Celik, E., Taş, H., Cay, T., Işik, S., \& Usta, A. T. (2018). Coexistence of adenomyosis, adenocarcinoma, endometrial and myometrial lesions in resected uterine specimens. Mol. Clin. Oncol., 9(2), 231-237. doi: 10.3892/ mco.2018.1660

[27] Tingthanatikul, Y., Lertvikool, S., Rodratn, N., Waiyaput, W., Dittharot, K., Sroyraya, M., \& Sophonsritsuk, A. (2018). The Effects of Dienogest on Macrophage and Natural Killer Cells in Adenomyosis: A Randomized Controlled Study. Int. J. Fertil. Steril., 11(4), 279-286. doi: 10.22074/ijfs.2018.5137.

[28] Tze-Sing, H., Yi-Jen, C., Teh-Ying, C., Chih-Yao, C., Hsin-Yang L., Ben-Shian, H., \& Muh-Hwa, Y. (2014). Oestrogen-induced angiogenesis promotes adenomyosis by activating the SlugVEGF axis in endometrial epithelial cells. J. Cell. Mol. Med., 18(7), 1358-1371. doi: $10.1111 / \mathrm{jcmm} .12300$.

[29] Vlahos, N. F., Theodoridis, T. D., \& Partsinevelos, G. A. (2017). Myomas and Adenomyosis: Impact on Reproductive Outcome. Biomed. Res. Int., 5926470. doi: 10.1155/2017/5926470.

[30] Zakharenko, N. F., Kovalenko, N. V., \& Manolyak, I. P. (2015). On the subject of complex therapy of endometriosis. Reproductive endocrinology, 23(3), 28-33.

\section{РОЛЬ СТЕРОЇДНИХ РЕЦЕПТОРІВ У ПАТОГЕНЕЗІ АДЕНОМІОЗУ ЗА НАЯВНОСТІ СУПУТНЬОЇ ПАТОЛОГІЇ ЕНДОМЕТРІЯ В ПОСТМЕНОПАУЗІ

Встановлення ланок патогенезу аденоміозу у жінок в постменопаузі є перспективним дослідженням, яке дозволить ретельніше вивчити механізми гормональних змін і вирішити питання, пов'язані з аденоміозом у жінок репродуктивного віку. Мета роботи - встановити роль стероїдних рецепторів у патогенезі аденоміозу за наявності супутньої патології ендометрія в постменопаузі. Матеріалом для дослідження були матки, видалені з придатками, 117 пацієнток віком від 49 до 76 років. Всі пацієнтки були розділені на 4 групи залежно від наявності аденоміозу та фронової патології (ендометріоїдна карцинома ендометрія (ЕКЕ) і гіперплазія ендометрія (ГПЕ)): 1) 27 жінок з аденоміозом і ГПЕ; 2) 30 жінок з аденоміозом та EKE; 3) 30 жінок з аденоміозом та віковими змінами в ендометрії; 4) 30 жінок з віковими змінами без аденоміозу (група порівняння). Імуногістохімічну реакцію проводили з використанням первинних антитіл до естрогенових (ЕR), прогестеронових $(P R)$ і андрогенових (AR) рецепторів. Cтатистичну обробку проводили із застосуванням параметричних методів варіаційної статистики (вираховували середнє арифметичне, стандартне відхилення, довірчий інтервал, критерій Стьюдента). Встановлено переважання рівня експресії ER у залозистому і стромальному компонентах еутопічного ендометрія за наявності аденоміозу і гіперпластичних процесів порівняно з групою порівняння (p<0,01). Вищий рівень експресії естрогенових рецепторів був більш характерним для епітелія ендометрія з гіперплазією $(7,333 \pm 0,314)$ та ендометріоїною карциномою 


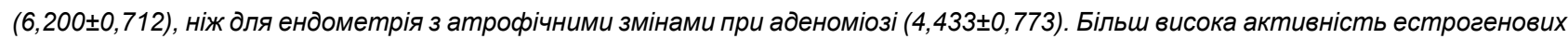
рецепторів у стромі виявлена при гіперплазії ендометрія $(7,148 \pm 0,276)$, ніж при атрофічних змінах $(4,567 \pm 0,738)$ та ендометріоїдній карциномі $(4,167 \pm 0,602)$. Встановлено, що в епітелії вогнищ аденоміозу при атрофрії експресія естрогенових рецепторів були нижчою $(3,433 \pm 1,074)$, ніж у фокусах аденоміозу при ендометріоїдній карциномі ендометрія $(4,667 \pm 0,526)$ та його гіперплазії $(5,148 \pm 0,745)$. У стромі фокусів аденоміозу експресія естрогенових рецепторів вища при гіперплазії ендометрія, ніж при ендометріӧ̈ній карциномі ендометрія та атрофрії. Активність прогестеронових рецепторів в еутопічному ендометрії знижується від простої неатипової до комплексної атипової гіперплазії ендометрія, а у пацієнток з аденоміозом та ендометріоїдною карциномою ендометрія - по мірі зниження ступеню диференціації клітин ЕКE (від G1 до G3 EKE). У групі порівняння виявлена мінімальна експресія прогестеронових рецепторів. У клітинах внутрішнього ендометріоза наявні позитивні показники імуногістохімічної реакції з PR. Отримані мінімальні бали рецепторної експресії андрогенових рецепторів в еу- та ектопічному ендометрії. Таким чином, фоокуси аденоміозу здійснюють регуляторний вплив на еутопічний ендометрій, стимулюючи експресію естрогенових рецепторів $і$, в меншій мірі, прогестеронових рецепторів, і не впливають на рівень андрогенових рецепторів в еутопічному ендометрії.

Ключові слова: аденоміоз, постменопауза, естрогенові рецептори, прогестеронові рецептори, андрогенові рецептори.

\section{РОЛЬ СТЕРОИДНЫХ РЕЦЕПТОРОВ В ПАТОГЕНЕЗЕ АДЕНОМИОЗА ПРИ НАЛИЧИИ СОПУТСТВУЮЩЕЙ ПАТОЛОГИИ ЭНДОМЕТРИЯ В ПОСТМЕНОПАУЗЕ \\ Гончаренко А.Ю.}

Определение звеньев патогенеза аденомиоза у женщин в постменопаузе является перспективным исследованием, которое позволит более тщательно изучить механизмы гормональных изменений и решить вопросы, связанные с аденомиозом у женщин репродуктивного возраста. Цель исследования - установить роль стероидных рецепторов в патогенезе аденомиоза при наличии сопутствующей патологии эндометрия в постменопаузе. Материалом для исследования служили матки, удаленные с придатками, 117 пациенток в возрасте 49-76 лет. Все пациентки были разделены на 4 группы в зависимости от наличия аденомиоза и фоновой патологии (эндометриоидная карцинома эндометрия (ЭКЭ) и гиперплазия эндометрия (ГПЭ)): 1) 27 женщин с аденомиозом и ГПЭ; 2) 30 женщин с аденомиозом и ЭКЭ; 3) 30 женщин с аденомиозом и возрастными изменениями в эндометрии; 4) 30 женщин с возрастными изменениями без аденомиоза (группа сравнения). Иммуногистохимическую реакцию проводили с использованием первичных антител к эстрогеновым (ER), прогестероновым $(P R)$ и андрогеновым (AR) рецепторам. Статистическую обработку проводили с применением параметрических методов вариационной статистики (вычисляли среднее арифметическое, стандартное отклонение, доверительный интервал, критерий Стьюдента). Установлено преобладание уровня экспрессии эстрогеновых рецепторов в железистом и стромальных компонентах эутопического эндометрия при наличии аденомиоза и гиперпластических процессов по сравнению $c$ группой сравнения $(p<0,01)$. Высший уровень экспрессии эстрогеновых рецепторов был более характерен для эпителия эндометрия с гиперплазией $(7,333 \pm 0,314)$ и эндометриоидной карциномой эндометрия $(6,20 \pm 0,712)$, чем для эндометрия $c$

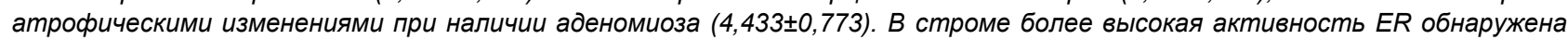
при гиперплазии эндометрия $(7,148 \pm 0,276)$, чем при атрофических изменениях $(4,567 \pm 0,738)$ и ЭКЭ $(4,167 \pm 0,602)$. Установлено, что в эпителии очагов аденомиоза ниже показатели экспрессии эстрогеновых рецепторов были при атрофии $(3,433 \pm 1,074)$, чем в фоокусах аденомиоза при эндометриоидной карциноме $(4,667 \pm 0,526)$ и гиперплазии эндометрия $(5,148 \pm 0,745)$. B строме фокусов аденомиоза экспрессия эстрогеновых рецепторов выше при гиперплазии эндометрия, чем при эндометриоидной карциноме эндометрия и атрофрии. Активность $P R$ в эутопическом эндометрии снижается от простой неатипичной к комплексной атипичной ГПЭ, а у пациенток с аденомиозом и эндометриоидной карциномой эндометрия - по мере снижения степени диффференциации клеток ЭКЭ (от G1 до G3 ЭКЭ). В группе сравнения обнаружена минимальная экспрессия PR. B клетках внутреннего эндометриоза присутствовали положительные показатели иммуногистохимической реакции $c$ PR. Получены минимальные баллы рецепторной экспрессии AR в эу- и эктопическом эндометриях. Таким образом, фрокусы аденомиоза осуществляют регуляторное влияние на эутопический эндометрий, стимулируя экспрессию ER и, в меньщей степени, $P R$, и не влияют на уровень $A R$ в эутопическом эндометрии.

Ключевые слова: аденомиоз, постменопауза, эстрогеновые рецепторы, прогестероновые рецепторы, андрогеновые рецепторы. 